Carlos Pereda, La filosofía en México en el siglo XX (Apuntes de un participante), 2013, México, Conaculta, 440 pp.

RECEPCIÓN: 28 de octubre de 2013.

ACEPTACIÓN: 12 de noviembre de 2013.

\title{
Carlos Pereda: una guía de lectura de la filosofía mexicana
}

$\mathrm{E}$ libro es uno de aquellos cuyos lectores no especializados en la materia agradecen enormemente. Lo primero que hay que señalar es que no se trata, como lo matiza el subtítulo, de una historia de la filosofía en México en ese lapso, pero que sí apunta en ese sentido, pues establece mapas colectivos, zonas de acción y retratos individuales; también que, al no plantearse como una historia, no responde a un impulso didáctico, pero sí de divulgación; no busca, en nombre de esa función divulgativa, rebajar el nivel de lo que se escribe para facilitar su consumo. El volumen reúne textos de muy diversa índole y aliento, desde breves recensiones de libros, hasta mapas y panoramas de cierta ambición, escritos a lo largo de muchos años, al menos 30; sin embargo, guarda una enorme coherencia, a la vez que convierte lo que podrían ser defectos -dispersión, diferencias de tono, diversidad de los objetivos de cada texto- en virtudes; por ejemplo, su heterogeneidad funciona al ensamblarse en libro como un abanico de posibilidades de lectura de la filosofía mexicana, como una guía de viaje por ese territorio, sin imponer sugerencias, pero con la necesaria información, de modo que facilita al viajero la elección de su itinerario.

Carlos Pereda es un filósofo de origen uruguayo afincado en México desde hace ya muchos años y es, en efecto, un participante del viaje reflexivo mexicano e hispanoamericano, participante -hay que decirlo- con un pensamiento propio, una voluntad de claridad y una saludable postura no dogmática. Es decir, reúne cualidades no tan frecuentes en el pensamiento 
iberoamericano; además, es un hombre culto, que en su ejercicio reflexivo no sólo atiende a la filosofía en sí, sino a lo que se piensa desde la literatura, el arte y otras disciplinas humanísticas. Tiene una visión secuencial de la tradición reflexiva y valora las individualidades; a esto habría que agregar que es un filósofo con buena prosa y atento a la poesía.

Su libro no es un texto pensado metódicamente; si bien no es dogmático ni juega sus fichas en un tablero ideológico, sino construido por el tiempo y el azar al reunir los textos y reseñas por encargo, las entrevistas y los panoramas históricos acumulados en la carpeta del escritor durante años, reúne también las páginas de un diario de lector. Él mismo señala en la introducción que no buscó hacer una historia ni unificó los textos en estilo y tono, salvo las minucias al uso en la recopilación de ensayos diversos, muy bien organizados y que cumplen una función histórica; para el lector no especializado se puede leer sin dificultad, incluso en sus pasajes más técnicos, y ofrece una interesante visión personal de lo sucedido en la filosofía mexicana; para el especializado, es una visión sintética del rostro filosófico que le permite reconocerse. Creo que será un libro muy útil tanto para los estudiantes de filosofía (o de carreras humanísticas) como para aquellos lectores que buscan, sin ser especialistas, orientarse en ese campo.

Establece primero una etapa ya clásica, la de los fundadores o refundadores del pensamiento mexicano a principios del silgo XX: Vasconcelos,

184 Caso, Ramos; una segunda etapa con la llegada vivificadora de los filósofos del exilio español, Joaquín Xirau, María Zambrano, Eduardo Nicol y varios más con José Gaos a la cabeza; una tercera que él llama de los grandes bloques, y que se podría entender como el desarrollo de las escuelas: Leopoldo Zea, el grupo Hiperión, los positivistas lógicos y el marxismo. Si bien las dos primeras miradas y sus respetivos mapas son claros e ilustrativos, tal vez sean un tanto parcos, mientras que la tercera reviste un interés incluso polémico, en la que el autor se asume más como participante, pues no sólo describe, sino que discute algunos puntos y se muestra deudor en otros. La impresión que yo tenía de ese grupo, en el que están Luis Villoro, Alejandro Rossi y Fernando Salmerón, es que la influencia mayor era la del existencialismo sartreano y en estas páginas esa presencia se modifica al apoyarse, para su taxonomía, más en los parentescos metodológicos que en las elecciones existenciales.

La oposición o polaridad entre Vasconcelos -hombre político y de acción, extraordinario memorialista y filósofo un tanto delirante y poco riguroso-se contrapone a la sobriedad y mayor rigor de Caso, que representa la imagen 
y labor del filósofo profesional, vinculado a las aulas universitarias y no a la plaza pública; en Ramos se puede encontrar cierta síntesis dialéctica de ambos fundadores, ya con una visión más específica, como la psicología del mexicano, línea de desarrollo muy importante y que, sin embargo, Pereda deja de lado, pues sin negar su importancia, se ha vuelto ya un lugar común de nuestras descripciones históricas y artísticas y a veces produce un hecho nada aconsejable: el tema justifica el argumento y no a la inversa. Eso se traduce en que Pereda diluye las falsificaciones nacionalistas en el recorrido integral -esta u otra filosofía es importante porque la piensa un mexicano-, con la estrategia de subrayar el contenido que importa por su argumentación y no por su nacionalidad. Así hay que entender la expresión "La filosofía en México", del título, diferente a "La filosofía mexicana".

En lo que se refiere a los filósofos transterrados se respeta un hecho que parece ya incontrovertible: el magisterio de José Gaos. Creo que, sin negarlo, valdría la pena buscar otro enfoque: la filosofía y la actividad docente del autor de Orígenes de la filosofía es sin duda la más influyente, pero no pienso que sea el pensamiento con mayor importancia ni el más leído hoy día (en lo primero, situaría la filosofía de Nicol; en lo segundo, la de María Zambrano). El universo de la filosofía de los transterrados es muy amplio y diverso, y cuando se le ha estudiado se suele adoptar un punto de vista español y no mexicano; Pereda, en vez, establece los parámetros extremos: el pensamiento de Gaos, que ha dado sobre todo una escuela histórica de reflexión e investigación, y el de Zambrano, vinculado a la idea de revelación y a su manifestación en la poesía. Es probable también que estos polos los escoja porque en su opuesta diversidad son los dos transterrados que encuentra más cercanos a su propio pensamiento.

A lo largo de los textos reunidos, Pereda deja pistas de lo que considera la opción y el deber de la filosofía; cuando se ocupa de los grandes bloques y retrata a algunos de los filósofos de la generación de medio siglo, a la vez que elige un interlocutor privilegiado -Luis Villoro, sin excluir su admiración por otros pensadores-, afirma el valor de la duda, una especie de principio de incertidumbre metodológico, similar al formulado por la ciencia y con raíces en el pensamiento clásico, de Descartes y de Platón. Tal vez en la lectura de diferentes textos de Villoro muestra Pereda mejor su talante crítico, a la par de su pertenencia a una tradición; creo que Villoro es el pensador frente al cual se define el pensamiento mexicano posterior al 68, en el último medio siglo, y que si bien la obra y la enseñanza de Zea son históricamente 
incontrovertibles, no son sus imperativos reflexivos los que ahora nos interesan. Villoro, en su preocupación por la historia, realiza la crítica del nacionalismo convertido en demagogia y retórica, y desde la historia regresa a la filosofía, restituyendo el camino que se había apartado de ella en las enseñanzas de Gaos; en Villoro, la pertenencia a un proceso reflexivo duro, ligado a la academia, no impide pensar, también y de forma simultánea, políticamente. Las veces que tanto Salmerón como Rossi y el propio Villoro se ocupan de formas filosóficas más técnicas -hay que recordar que Rossi, después de su primer libro, Lenguaje y significado, de filosofía dura, se pasa con éxito notable a la literatura-, permite a esa generación apoyarse en la metodología histórica y en la sistematización conceptual; Pereda les reprocha, sin embargo, la de vincularse a escuelas o corrientes del pensamiento. Ramón Xirau, por su lado, aporta un elemento muy importante: el pensamiento religioso, presente en los refundadores y en muchos de los exiliados, mientras Adolfo Sánchez Vázquez lo hace con el marxismo como sistema y no únicamente como ideología; a su vez, ambos, desde muy distintos puntos de vista, configuran una estética y se vinculan a la poesía, género expresivo que también practican.

Sin que Pereda lo señale explícitamente, los trabajos de Juliana González, tanto su aproximación a Nietzsche como su interés posterior por la bioética, sitúan a la filósofa en un momento de cambio clave: el tránsito de la generación marcada por Gaos y la disolución, casi se diría que el derrumbe, de la presencia del marxismo, así como la aparición de una variedad de inflexiones de la filosofía, a la que se suman reflexiones de las ciencias duras, de la historia, de la medicina y de ciencias humanas, como la lingüística. Pereda la llama "La irrupción del archipiélago". No hay que dejar de señalar que Juliana González es una golondrina que sí hace verano, por la aparición de importantes aportes de mujeres a nuestra filosofía.

Por razones naturales, entre otras la propia diversidad y cantidad de islas que forman el archipiélago, Pereda describe con trazos más rápidos las características de algunos autores, muchos de ellos contemporáneos suyos o más jóvenes, y el término participante del subtítulo vuelve a cobrar importancia: en esa dispersión o diseminación me parece sintomático de las estrategias de lectura de Pereda que aparezca poco el pensador francés Michel Foucault; en parte, eso también provoca que se atienda poco al pensamiento histórico, una de las ramas más ricas de la influencia de Gaos que, a partir del autor de Vigilar y castigar, sufre un fuerte giro conceptual. 
En parte, esto se explica por el apartado tres, dedicado a "La recepción de la filosofía alemana en México", en colaboración con Gustavo Leyva, uno de los capítulos más interesantes del libro. No sé si alguien ha hecho algo similar sobre el pensamiento francés o anglosajón; desde luego, es interesantísimo ver cómo fluye la influencia germana, ya sea triangulada por medio de Francia o de España, gracias a Ortega, o cuando se realiza una lectura más directa, ya no en traducciones. Las denuncias de los defectos "sucursaleros"de nuestra reflexión toman allí un cuerpo tangible; el texto sobre la influencia alemana responde precisamente a esa idea de mapa que mencioné, y permite entender ciertas cosas de detalle al proporcionar una visión de conjunto: la presencia de Hegel, por ejemplo. Pereda conoce directamente el pensamiento alemán y recibe su influencia sin rendirle una pleitesía escolar, pero es innegable que lo influye más que otros; por otro lado, el pensamiento francés llegó a un cierto callejón sin salida, no después de Foucault, sino ya en la misma obra del autor galo. Estrictamente, en el terreno de la historia pareció haber un divorcio entre las metodologías compiladoras y las interpretativas, en las que el dato duro se encontraba con la explicación blanda, y la interpretación dura, casi siempre ideológica, acomodaba los datos a su conveniencia. Otro autor francés poco presente es Deleuze; en buena medida, se debe a que su lectura se realiza sobre todo en una generación posterior al archipiélago y que, junto a otros pensadores como Roland Barthes, influye tal vez más en la literatura que en la filosofía.

El libro da cuenta, sin detallarlo, de dos derrumbes claros: por un lado, el de la filosofía de índole escolástica, a partir del medio siglo mexicano; por otro, el de la filosofía marxista, a partir de los setenta. Sin embargo, creo que ambos derrumbes no impiden que dichas corrientes, de manera subterránea, tengan una deriva muy interesante en autores que ya no alcanza a tocar el texto; en el terreno del marxismo hay que estudiar, por ejemplo, las obras de Adolfo Gilly, de carácter claramente político, y las de Roger Bartra, que se adscribe a la corriente hasta La jaula de la melancolía y, tal vez, su díptico sobre El salvaje -ya no, en cambio, en su obra más reciente, sobre cuestiones biológicas, el exocerebro y las prótesis.

Al abrir la sección cuatro del libro, con un apartado sobre "Los bordes de la filosofia", Pereda se adentra en el cambio sustancial que marca los últimos años: la práctica del ensayo. México tiene una tradición importante en ese género, que vivió una época dorada desde el siglo XIX pero, particularmente, entre la Generación del Ateneo y la de Medio siglo; después, tuvo un 
fuerte descenso cualitativo, al sufrir tanto la esclerosis académica como la verborrea del nuevo periodismo, encabezada por Carlos Monsiváis, y el fuerte golpe de la represión en 1968. La tradición tardó en recuperarse, pero nuevamente fue la vena literaria, mediante escritores como Hugo Hiriart o Federico Campbell, que retomó el camino; en el terreno filosófico, con nuevos bríos precisamente en sus bordes o márgenes. La propia generación de Pereda retoma la reflexión sobre el género, al plantearlo como tema y al aplicar su dinámica a perspectivas diferentes; autores como Liliana Weinberg, Luis Fernando Lara y Claudio Lomnitz representan esos bordes, a los que se debería dar más atención debido a que se han desbordado ya en autores más jóvenes, como Salvador Gallardo, Francisco Segovia y Daniel González Dueñas.

Liliana Weinberg ha hecho una especie de fenomenología ensayística del ensayo, sin restringirse a una obligación genérica definitiva (y, además, imposible), que permite retomar la labor de Reyes, Paz, Fuentes y Tomás Segovia, cuyos textos, más allá de su filiación literaria en un sentido amplio, o incluso en un sentido estricto, plantean una crítica del poder y del sentido, una transformación de los bordes - expresión que hace pensar en una filosofía concebida a la manera precopernicana-en márgenes. La expresión misma, si la tomamos en sentido cartográfico, tiene algo de terreno de nadie, sin propietario; de allí que el estudio de un caso localizado y concreto, muy especializado, como ejemplifica Luis Fernando Lara al hablar del diccionario monolingüe, le permite a Pereda plantear sin formularla explícitamente la propuesta de que todo ensayo es la puesta en escena de la disyuntiva hermenéutica entre descripción y normatividad, y que el ensayo como género elude ambas al situarse, no en la otra orilla, sino en el río mismo. Por eso, el ensayo no es dogmático y quiere (y debe) ser crítico.

En la página 336 del libro, aparece plenamente lo que es un lugar común de la filosofía mexicana: el dilema entre Ariel y Calibán, mismo que Pereda mediante su comentario sobre Modernidad indiana de Lomnitz, señala como una falsa polaridad, o mejor dicho, una polaridad entre posiciones equívocas. Los Méxicos profundos se revelan tan superficiales como sus contrapartes cosmopolitas, cien años después de Darío. Pereda apunta hacia una "razón porosa" (el término aparece varias veces a lo largo del libro) dejando atrás las razones metafísicas (no se me escapa la contradicción de ese término), las lógicas, las matemáticas, las económicas y hasta las históricas. Pero no las éticas. Por eso la saludable inmersión, que no regreso, a Spinoza y a Leibniz. El desafío es pensar libremente. Las trabas para ese pensar libre y en libertad no suelen ser sólo metodológicas o de elección entre la tendencia a repetir discursos 
de las grandes figuras o el afán de novedad que obtiene su valoración en la novedad misma, vuelta obsoleta al día siguiente. Tal vez sea cierto el reproche que Pereda hace a los críticos literarios -lo tonto de su antiteoricismo-, pero también es cierto que el problema es que se han quedado, como antes los filósofos, sin lectores, y eso - además de la tristeza individual- provoca estancamiento colectivo; esa falta de diálogo que Pereda denuncia una y otra vez, y que sin embargo la fluidez de su libro parece desmentir.

En el diálogo con Josu Landa parece plasmarse algo claramente: la diferencia entre razón y razones. El plural es aquí un salto de nivel, no una diferencia cuantitativa. Josu Landa, que se define como un filósofo que se interesa en la literatura, pero que yo describiría a la inversa, un escritor con preocupaciones filosóficas, nos describe con claridad la postura "correcta" en el pensamiento actual. No basta esa ecuanimidad, pues parece un tanto pasteurizada de sus factores bárbaros; Ariel descubre su mejor arma en la condescendencia hacia Calibán. El vigor no depende de su condición austera o enfática; por ejemplo, en Nietzsche es evidente que hay un énfasis austero, al hacer uso de algo que llamaría la razón confesional, en un sentido muy distinto de lo que se entiende comúnmente, y que tendría sus raíces en María Zambrano y en Rosa Chacel (la gran novelista española es autora de un peculiar y olvidado libro: La confesión). Y también en ese diálogo aparece un subrayado genérico: ese tránsito de la escritura ensayística hacia el fragmento en sus diversas modalidades. Pero este es un tema que excede el marco de esta reseña. Al igual que la excede la idea de establecer un mapa más actual del pensamiento contemporáneo, en el que se acepte ya sin reticencias el entreverado destino de la filosofía y la literatura en los años por venir. En ese dialogo aparece un subrayado genérico: ese tránsito de la escritura ensayística hacia el fragmento en sus diversas modalidades. La razón porosa se erige como alternativa frente a la razón arrogante. Esta última se define por su incapacidad para escuchar; en la línea que sea, su discurso se impone por sí mismo, no por su argumento. Pero esa razón no sólo no escucha, sino que no deja que otras argumentaciones se oigan, y para ello sube el volumen, habla fuerte, grita. Y también controla foros de discusión-revistas, editoriales, congresos-, y acaba por convertirse en una burocracia y/o una iglesia.

La expresión ambigua e incluso confusa de "pensar en español" es, sin embargo, bien entendida: pensar, aquí y ahora, sin complejos, sin fervores sucursaleros y sin afán de novedades, y también (ya se ha agregado este tercer vértice) sin afanes nacionalistas. Pensar tiene lugar, no nacionalidad, tiempo, horario. La filosofía en México en el siglo XX es un libro que debería tener 
RESEÑAS

muchos lectores y que debería facilitar nuevos contextos reflexivos, no porque encontremos en él nuevos gurús ni tendencias reafirmadas en sí mismas. Pereda pone en el centro de su quehacer y de su historiar la duda (él la llama incertidumbre). Las certezas son un virus que corroe al pensamiento, incluso cuando aceptamos que esa es su labor: buscar certezas, pero buscarlas, no encontrarlas, y mucho menos imponerlas. Insisto en que eso está ocurriendo ya en el terreno más estrictamente literario, pero que ya se aprecia también en el terreno de la estética y la filosofía (menos en el de la filosofía de la ciencia).

JOSÉ MARÍA ESPINASA

Poeta y editor 